\title{
Efforts to Control Fictitious Order Crime by Grab Online Transportation Drivers in Indonesia and Malaysia (Study at Pt Solusi Transportasi Indonesia)
}

\author{
Patar Mangimbur Permahadi', Kartina Pakpahan ${ }^{2}$, Tommy Leonard ${ }^{3}$, Mulyadi ${ }^{4}$, Iin Hot \\ Prinauli Purba ${ }^{5}$ \\ \{patarmahady8686@gmail.com', kartinapakpahan@unprimdn.ac.id², tommy-journal.ac.id ${ }^{3}$, \\ mulyadiunpri@gmail.com ${ }^{4}$ \}
}

Universitas Prima Indonesia ${ }^{12345}$

\begin{abstract}
During the modernization era, the development of information and communication technology is growing very rapidly. One of these technological developments can be seen in the field of online-based which can help people to go to a place or send goods using only online transportation applications via android cellular. However, advances in online-based transportation technology are often misused by unscrupulous perpetrators in carrying out fictitious orders or more commonly called "order fictive". more ironically, the perpetrators of these crimes are the drivers of online transportation itself in order to achieve targets that are self-beneficial. The purpose of this paper is to determine the form of fictitious order handling efforts conducted by online transportation drivers in Indonesia. This research is a type of empirical juridical approach. The type of research used in this paper is a legal research that is empirical juridical, that is research whose object of study includes by conducting research by collecting primary data. As well as the statutory provisions (in abstracto), as well as their application to legal events (in concreto). The results of this study are that in providing a criminal law policy in the future in tackling criminal acts fictitious orders do not have to be preventive in the form of oppression through the prosecution or court, but rather implementing crime prevention through non-criminal channels or without the courts.
\end{abstract}

Keywords: Mitigation Efforts; Online Grab Transportation Drivers; Fictitious Orders

\section{Introduction}

Information technology and communication have globally altered people's behaviour and patterns. The development of information technology has resulted in an infinite (boderless) world and also in significant changes in, social, cultural, economic and pattern of law enforcement that are taking place very rapidly. Information technology today has become a double-edged sword, contributing to the improvement of welfare, the progress and civilization in both, an effective means of change against the law. The misappropriation of information and communication technology development at present is the Internet connection network (subsequently called Internet).

The Internet provides an information medium and electronic communication that is widely exploited by people on a variety of activities, such as browsing, searching data and news, mailing one another by email, communicating through a social network, and including 
commerce by electronic commerce, or e-commerce for short. As for e-commerce's trademark the exchange of goods and services, information on the use of electronic media. One form of e commerce is booming this is an online transport business. Some examples of an online transport company in Indonesia that have developed since 2014 are:

1. Uber

Uber is an American transport network that USES smart apps for car reservations except the fleet of cars that are used is not public transport yellow plate but black-cop private cars with uber logo.

2. Go-jek

Leads to the principle of the applications and applications work by bringing in a request for passenger transport through a motorcycle taxi service operating around the passenger area. If you download an application from Google play store, you can order the service. Transport rates are adjusted at mileage to be reached. Passenger transport also served delivery (Courier and shopping).

3. Grab

Grab almost looks like a go-jack, just grab services hasn't had an end-to-shopping delivery service. Currently grab has operated in three countries in the region of southeast Asia such as, Malaysia, Vietnam and Indonesia.

A legal link between a driver and an online transportation services services like grab is a partnership agreement, as arranged in article 1313 of the civil law book (further called kuhper). As for the legal requirements of a covenant according to article 1320 kuhper there are four in which the parties (consensus) agree, the two be lawful or lawful, the three objects must be clear, the four allowed kausa (kosher). A special partnership was formed in 1618 kuhperdchapters 1652 kuhper in the corresponding civil alliance (maatschaap) or venootschaap according to the Dutch.

The formation of a partnership agreement that is easy, such as establishing a maatschaap does not require special skills, is broader in nature and is relatively easy and simple and more flexible to provide more value than a partnership agreement. This advantage is what makes a number of people willing to join online transportation because they don't. the need for higher education, is not bound by busy working hours and does not have to bother looking for passengers, they are free to choose whether to take orders or not. For partner companies this is very profitable because it does not need to be bound by labor regulations such as wage arrangements and payment of severance pay.

Several online transportation provider companies such as those that develop with a partnership pattern, often cause problems such as violations of the partnership agreement as in Decision No 1508 / Pid.Sus / 2018 / PN. Medan, July 24, 2018. Based on the description above, it is important to discuss and conduct research on "Efforts to Control Fictitious Order Crime by Grab Online Transportation Drivers in Indonesia and Malaysia (Study at PT Solusi Transportasi Indonesia)"

Formulation Based on the description above, the problems in this thesis are:

1. What is the legal position between online transportation drivers and PT. Grab Indonesia?

2. What factors led to a fictitious order crime (fraud) at PT. Grab done by the driver?

3. How are the efforts to tackle the fictitious orders of PT.Grab Indonesia and Malaysia?.

In this paper, the theoretical framework used is the theory of legal tackling (criminal policy) as the ultimate goal or main objective of law which becomes a legal policy to provide protection for the community (social defense) and create social welfare. 
According to Muladi, the policy of overcoming the law, when viewed in scope, is very broad and high in complexity. This is natural because in essence crime is a humanitarian problem and is a social problem that requires its own understanding. Crime as a social problem is a dynamic, always growing symptom that is related to other very complex symptoms and social structures. It is a social-political problem.

According to Barda Nawawi Arief, said that the prevention of crime can be broadly divided into two, namely through the "penal" route and through the "non-penal" route (not / outside the criminal law). Efforts to control crime through the penal route focus more on efforts that are "repressive" (suppression / eradication / eradication), after the crime has occurred. Efforts to control crime through the non-Penal route are more of a preventive measure for the occurrence of crime, so the main objective is to address the factors conducive to the occurrence of crime.

These conducive factors, among others, focus on social problems or conditions that can directly or indirectly cause or promote crime. Thus, seen from the point of view of criminal politics at a macro and global level, non-penal efforts occupy a key and strategic position in the overall criminal political effort. In various UN congresses on "The Prevention of Crime and Treatment of Offenders" strategic efforts were emphasized regarding overcoming the causes of crime.

Conception

Conceptual framework is a framework that connects or describes specific concepts which are a collection of meanings related to that term:

a. Crime prevention efforts are known by various terms, including penal policy, criminal policy, or strafrechtspolitiek, which is an attempt to tackle crime through criminal law enforcement, which is rational, namely fulfilling a sense of justice and efficiency. In the context of overcoming crimes against various means as a reaction that can be given to the perpetrators of crime, in the form of criminal and non-criminal legal means, which can be integrated with one another.

b. Criminal action is a translation of "straafbaarfeit", in the Criminal Code (hereinafter abbreviated as KUHP) there is no explanation of what exactly is meant by straafbaar feit itself. Usually, a criminal act is synonymous with offense, which comes from the Latin word delictum. In the Big Indonesian dictionary, it is listed as follows "offense is an act that can be subject to punishment because it is a violation of the criminal act law".

c. A fictitious order is an order that was incorrectly ordered and executed by trickery

d. Grab online is a company from Singapore that serves transportation provider applications and is available in six Southeast Asian countries such as Malaysia, Singapore, Thailand, Vietnam, Indonesia and the Philippines.

\section{Research Methods}

This research will discuss about how the legal position between transportation drivers and PT. Grab Indonesia, what factors led to the crime of fictitious orders at PT. Grab Indonesia carried out by the driver and how the efforts to tackle the crime of fictitious orders of PT. Grab in Indonesia and Malaysia. This type of research used in this writing is legal research that is juridical empirical, namely research whose object of study includes conducting research by collecting primary data obtained directly from the first source directly from the results of field 
research, both through observation and interviews with parties who are directly related to the problem of writing this thesis.

As well as statutory provisions (inabstracto), as well as their application to legal events (in concreto) related to issues to be discussed in this paper. In general, secondary data is ready to be made and can be used immediately. After the data has been collected, the data obtained from further research is analyzed using qualitative analysis, namely by describing the data and facts produced or in other words, describing the data with sentences that are arranged in a detailed, systematic and analysis way, so that it will make it easier make conclusions from field research with an interpretation, evaluation and general knowledge.

\section{Results and Discussion}

\subsection{The Legal Relationship Between Online Transportation Drivers and Pt. Grab In Indonesia}

\section{a. Definition of Agreement}

A legal relationship is a relationship that is regulated by law, which contains reciprocal rights and obligations. One party has the right to demand something from the other party, and the other party is obliged to fulfill its demands, and vice versa. According to Soeroso, in principle, the law regulates the relationship between one person and another. All relations in society cannot be separated from the law. Therefore, a legal relationship is a relationship between two or more legal subjects. In this connection, the matters and obligations of one party face the rights and obligations of the other [1].

Based on the above definitions, basically law has two aspects, namely the aspect of power / authority or rights (bevoegheid) and the aspect of obligation (plicht). These rights and obligations arise as a result of an event that is regulated by law, as stated in Article 1457 of the Civil Code regarding the engagement (verbintenis), which arises as a result of an agreement (overeenkomst) [2]. A legal relationship that is regulated in an agreement as stipulated in Article 1313 of the Civil Code. An agreement is an event in which someone promises to someone or two people who bind themselves to each other to carry out something.

\section{b. Principle Of Consensualism.}

The principle of consensualism comes from the latent language of consensus which means agreement. The agreement is that between the parties an agreement is reached [3].

\section{c. Principle of Freedom of Contract.}

The principle of freedom of contract is a principle that an agreement must be free in accordance with the wishes of the parties provided that such freedom does not violate public order and morals. According to Sutan Remy Sjahdeini, freedom to contract according to the Civil Code includes:

1. Freedom to make or not make agreements;

2. Freedom to choose the party with whom he wants to make an agreement;

3. Freedom to determine or choose causa from the agreement that will be made;

4. Freedom to determine the object that was promised

5. Freedom to determine the form agreed upon; 
6. Freedom to accept or deviate from statutory provisions that are optional (aanvullend, optional) [4].

\section{d. The Principle of Binding Strength (Pacta Sunt Servanda)}

All agreements made by the parties bind those who make it into law. The parties must respect a law. Failure to implement the agreement has the same effect as if a person violates the law, namely being subject to legal sanctions [5].

\section{e. Principles of Good Faith}

The National Civil Law Symposium held by the National Civil Law Development Agency (BPHPN) in 1981 defines good faith, namely: there is honesty when making an agreement, at the stage of making it emphasizes if the parties are considered to be in good faith (although there are also opinions that object to it), as appropriateness in the implementation stage which is solely aimed at preventing inappropriate behavior in the implementation of the agreement [6].

\section{f. Principle of Balance}

In a promise means that the promise between the parties will be considered binding if it is based on the principle of balance which is the ultimate goal that the position of the parties is legally equal or equal.

\section{g. Covenant Consequences}

Based on Article 1338 of the Civil Code, an agreement made legally is binding as a law for the parties making it. In essence, this article states that there is freedom of contract but this freedom is limited by law which forces the parties to carry out what the parties have agreed to, but the agreement is not allowed to cause harm to the parties or the other party.

If one of the parties violates or breaks a promise, it can be said that an act of default has occurred. A person can be said to have committed an act of default, namely as follows:

1. A person does not fulfill any achievements at all;

2. Achievements are met, but not in accordance with what was promised;

3. Achievements are fulfilled but not on the agreed time;

4. Achievements are fulfilled but there is a violation in the agreement.

\section{h. Definition of Work Agreement}

A work agreement which in Dutch is usually called arbeidsovereenkoms, can be interpreted in several senses. The first definition is stated in the provisions of Article 1601a $\mathrm{BW}$, regarding a work agreement it is stated that a work agreement is an agreement in which one party is a laborer, binds himself under the orders of the other party, serve for a certain time, do work for a reward [7]. Based on the provisions of Article 1 point (14) of the Manpower Act, it is stated that "a work agreement is an agreement between a worker / laborer and an entrepreneur or employer which contains the working conditions, rights and obligations of the parties".

Then confirmed in Article 1 number (15) of Law no. 13 of 2003 concerning Manpower, it is stated that "the work agreement becomes the basis for the relationship between employers and workers or laborers based on a work agreement, which has elements of work, wages and orders." Based on the above understanding, in the work agreement there are three elements, namely work, wages and orders, which means that the employee has the right to claim his 
rights from the employer, while the employer also has the right to claim his rights from the employee and the employer must carry out his obligations to the employee and vice versa.

\section{i. Definition of Partnership Agreement}

Based on Article 1313 of the Civil Code, an agreement is an event where a person promises to one person or another party or where two people or two parties promise each other to carry out something. As a general agreement, the partnership agreement is subject to the provisions of Article 1338 in conjunction with Article 1320 of the Civil Code. Meanwhile, special provisions can refer to the provisions of civil partnerships in Article 1618 of the Civil Code up to Article 1641 of the Civil Code.

Article 1618 of the Civil Code defines an association as an agreement whereby two or more people bind themselves to include something in the partnership, with the intention of sharing the profits that occur because of it. Furthermore, Article 1619 stipulates that each partner is obliged to enter a capital as an inbreng, either in the form of goods. , money or craft or energy [8].

Apart from that, in a partnership agreement, the position of the parties has an equal position and there is no higher position as regulated in the labor law. The partnership agreement does not contain elements of wages and orders but for the results. Based on this, it can be said that what is meant by a partnership agreement is an agreement that is mutual in nature where the parties to the agreement have an equal position and, in the agreement, does not contain elements of wages and orders in other words in the partnership agreement using a profit- or profit-sharing system.

Regarding the partnership agreement, legal experts provide the following definitions:

1. According to Kian Wie, a partnership agreement is "a business cooperation between large or medium-sized companies engaged in the production sector of goods and in the service sector with small industries based on the principle of mutual need, mutual strengthening and mutual benefit[9].

2. According to Hafsah, a partnership agreement is "a business strategy carried out by two or more parties within a certain period of time to gain mutual benefits with the principle of mutual need and mutual growth [10].

3. According to Umar Kasim, a partnership agreement is "a general form of a legal relationship between one party and another on the basis of a partnership agreement. The form of the agreement to do work on the basis of a partnership, namely: production sharing agreement, agency agreement (either personally or corporation), nucleus plasma, sub - contract, payment agreement (deposit) for a certain amount of money, and others. [11].

Based on the above understanding, it can be concluded that the difference between a work agreement and a partnership agreement is as follows:

Table 1. work agreement and a partnership agreement

\begin{tabular}{|l|l|l|}
\hline \multicolumn{1}{|c|}{$\begin{array}{c}\text { The Element of } \\
\text { Difference }\end{array}$} & \multicolumn{1}{|c|}{ Partnership Agreement } & \multicolumn{1}{c|}{ Work Agreement } \\
\hline Legal Basis & Civil Law & Labour Laws \\
\hline Position of the parties & On par & Superior - Subordinate \\
\hline $\begin{array}{l}\text { Minimum clause in the } \\
\text { agreement }\end{array}$ & $\begin{array}{l}\text { and obligations of the } \\
\text { parties, form of } \\
\text { dispute resolution }\end{array}$ & $\begin{array}{l}\text { Name, company address and type } \\
\text { of business; gender, age and } \\
\text { address of the worker / laborer; } \\
\text { position or type of work; the } \\
\text { number of wages and the method } \\
\text { of payment the conditions of } \\
\text { work which contain the rights }\end{array}$ \\
\hline
\end{tabular}




\begin{tabular}{|l|l|l|}
\hline & & $\begin{array}{l}\text { and obligations of the } \\
\text { entrepreneur and the worker / } \\
\text { laborer; starting and the period of } \\
\text { validity of the work agreement } \\
\text { made and the signature of the } \\
\text { parties in the agreement. }\end{array}$ \\
\hline $\begin{array}{l}\text { Elements of wages and } \\
\text { orders }\end{array}$ & Not & Yes \\
\hline $\begin{array}{l}\text { Protection guarantees } \\
\text { such as overtime pay, rest } \\
\text { time, maximum working } \\
\text { hours, social security. }\end{array}$ & Unregulated & Regulated [12]. \\
\hline
\end{tabular}

The Position of The Legal Relationship Between Online Transportation Drivers and Online Transportation Companies in Indonesia.

Whereas the legal relationship between online transportation drivers and online transportation companies is based on the principle of a partnership agreement which is subject to Article 1313 of the Civil Code. The partnership agreement contract is based on three parties, namely the driver, the provider, namely PT. Grab Teknologi Indonesia, and application users. This was confirmed by Agus Mulya Karsona, who stated that the partnership relationship with the employment relationship had very basic differences, for example PT. Grab Teknologi Indoenesia as a service provider institution emphasizes mutually beneficial relationships or mutualism between the parties, namely the position of the parties such as drivers, PT. Grab Teknologi Indonesia and users are equal and the same.

The position of the legal relationship between online transportation drivers and Indonesian online transportation companies is stated in the agreement made through the application system which is subject to Article 18 paragraph (1) of Law number 19 of 2016 concerning amendments to Law Number 11 of 2008 concerning Electronic Information and Transactions which states that electronic transactions that are entered into an electronic contract are binding on the parties. Partnership cooperation between the driver and PT. Grab Indonesia is related to, among others, grab taxis, grab bikes, grab cars, grab food, grab marts, wholesale services, grab fresh, grab for business, grab health, and Indonesia bus market place which are partners of cooperation where each is a legal subject that stands alone and independently.

PT. Grab Indonesia Technology is the party that makes, owns and manages the grab application that registered consumers benefit from services between goods and / or people shuttle services, message services between goods or other services used with two-wheeled or four-wheeled motorized vehicles or other services,For delivery of goods, PT. Grab Teknologi Indonesia is affiliated and collaborates with PT. Indonesian delivery solutions, while for food delivery and transportation of people PT. Grab Teknologi validates and collaborates with PT. Grab Platform Indonesia.

Partners have the same position when referring to partnership theory and not subordinate relationships with superiors or workers and employers, that in practice the agreement between the Grab driver and PT. Grab Indonesia has a unique characteristic, namely in the signing of a partnership agreement between prospective drivers of PT. Grab Indonesia, which is given a contract that has been made by PT. Grab Indonesia or often called the standard contract where the prospective driver of PT. Grab must sign the contents of the contract that has been determined without being able to change or negotiate the contents of the contract. 
Based on the research results of PT.Grab Indonesia in the partnership agreement between the grab driver and PT. Grab Indonesia regulates the obligations that must be approved by grab drivers when installing the driver application, including:

1. In the event that you violate the code of ethics that you agree to and have sanctions for termination of the partnership and not returning your e-wallet balance, you hereby release and release and will not sue Grab for the remaining balance of your electronic wallet which is forfeited as a fine for the violation. the;

2. You will be solely responsible for any liability and any defamation caused by your actions, the operation of your motorized vehicle or passenger vehicle, and / or taxi or passenger delivery services, including, but not limited to individual injury, death. , and property damage;

3. You are ready to be responsible for any losses suffered by Grab Indonesia if you are found to have violated any clause in this Code of Conduct;

4. You are willing, the value of your balance in the driver's wallet to be taken back by Grab Indonesia, if you are proven to have committed misuse and a criminal act, or are blacklisted / terminated by your partnership, due to violating this Code of Conduct;

5. In the case of sexual violence violations committed by you:

a. You agree that, in the event that the report has been withdrawn and / or closed, Grab has the right, at its absolute discretion, to reopen the investigation of the report and make the reports and findings available, to continue further investigations if:

- The report that is revoked by the reporter is carried out on the grounds of intimidation and / or threats from the reported party, even though there has been a statement of peace between the reporter and the reported;

- There are allegations of attempts to cause the reputation of Grab to fall by the reported and / or reporter;

b. You agree that if and necessary for psychological counseling to you and / or psychological recovery for victims of sexual harassment, the costs associated with such counseling and / or recovery will be borne by you, which can be paid / withdrawn from your driver's wallet.

6. This code of conduct can be changed at any time unilaterally by Grab, so that you also declare that you will regularly review and always comply with the "Terms and Conditions of Service" and "Code of Ethics" as stated here and the official Grab Indonesia website at https: //www.grab.com/id/terms/driver/ [12].

Based on these provisions, it can be analyzed that there is an imbalance in the partnership agreement between the grab driver and PT. Grab Indonesia. The imbalance is very clear PT. Grab emphasized that the grab driver is willing, the value of the driver's balance in the driver's wallet to be taken back by Grab Indonesia, if the driver is proven to have committed abuse and a criminal act, or is blacklisted / terminated by a partnership, due to violating this Code of Conduct.

Besides, according to the contents of the partnership agreement between the grab driver and PT. Grab Teknologi Indonesia, then PT. Grab has the right to impose additional conditions other than those stated in the agreement and the driver must comply with the terms in the agreement. Every term and condition imposed by PT. Grab Teknologi Indonesia can be changed and added from time to time. 


\subsection{Factors Causing of Fictive Orderan Criminal Action (Fraud) At Pt. Grab Indonesia Definition of Crime and Elements of Criminal Actions}

The term criminal offense is a translation of "straafbaarfeit", in the Criminal Code there is no explanation of what exactly is meant by straafbaar feit itself. Usually, a criminal act is synonymous with offense, which comes from the Latin word delictum. In the Big Indonesian dictionary, it is listed as follows "offense is an offense that is punishable because it is a violation of the criminal act law' [13]. Regarding "offense" in the sense of straafbaarfeit, criminal law experts each provide the following definitions:

1. Adam Chawawi

Stating "Strafbaarfeit is known in criminal law, defined as offense, criminal event, and criminal act. Strafbaarfeit consists of 3 (three) words, namely straf, baar, and feit. Straf is defined as criminal and law, baar is defined as can and may. While feit is defined as an act, incident, violation, and deed. The English language is delict. It means an act for which the perpetrator is subject to punishment (criminal). " [14].

2. Pompe

The word straafbaarfeit theoretically can be formulated as a violation of norms (interference with legal order) which has been intentionally or unintentionally committed by a perpetrator, where the punishment of the perpetrator is necessary for the sake of maintaining legal order and ensuring public interest or as de normoveertreding. (verstoring der rechtsorde), waaraan de overtreder schuld heeft enwaarvan de bestraffing dienstig is voor de handhaving der rechts orde en de behartiging van hetalgemeen welzjin [15].

\section{Elements of Criminal Actions}

According to P.A.F. Lamintang, the elements of a criminal act can be divided into 2 kinds of elements, namely subjective elements and objective elements. Subjective elements, elements that are present or attached to the perpetrator, or those related to the perpetrator and include everything that is involved in the perpetrator. contained in his heart. The subjective elements of a criminal act are:

1. Willfulness or coincidence (dolus or culpa);

2. The purpose of an experiment, as specified in Article 53 paragraph (1) of the Criminal Code.

3. Various purposes, such as in the crime of theft, fraud, extortion, and so on.

4. Planning in advance, as stated in Article 340 of the Criminal Code, which is a murder that was planned in advance.

5. Feelings of fear as contained in Article 308 of the Criminal Code.

Objective elements are the elements that have a relationship with the performer and include everything that is contained in his heart. The objective elements of a criminal act are:

1. The nature of unlawful or wederrechtelijkheid.

2. The quality of the perpetrator, "the condition of being a manager or commissioner of a limited liability company" in crimes according to Article 389 of the Criminal Code.

3. Causality, namely the relationship between an action as a cause and a fact as a result [16].

According to Moelyatno, the elements or elements of a criminal act consist of:

1. Actions and consequences (actions). 
2. For example, Article 418 of the Criminal Code, if the conditions are not met then automatically the criminal act as referred to in the Article cannot exist, so it can be said that the criminal act in Article 418 of the Criminal Code exists if the perpetrator is a civil servant.

3. Matters or circumstances that accompany the action.

4. For example, in Article 160 of the Criminal Code, it is stipulated that incitement must be carried out in public, so it determines that the conditions that must accompany the sedition act are those committed in public.

5. An additional situation that burdens the criminal. The point is that without a certain additional condition, a defendant can be deemed to have committed a criminal act which is punishable by punishment, but with the additional circumstances, the threat of punishment is then weighted.

6. Elements against the law are objective.

Unlawful element which refers to the physical or objective condition that accompanies an act.

7. The element of against the law is subjective.

The element of breaking the law lies in the heart of a criminal himself. For example, Article 362 of the Criminal Code, there is a sentence "with the intention" this sentence states that the nature of the action against the law is the intention of a person to take goods. If his intentions are good, for example taking goods and then returning them to their owners, then the act is not prohibited. On the other hand, if his heart intentions are bad, which is to take goods to be owned by himself without ignoring the owner according to law, then this is prohibited and is included in the theft formula [17].

\section{Criminal Liability}

In positive criminal law, there is no concept of criminal liability. However, the concept of criminal liability can be found in the doctrine of criminal law. In the science of criminal law, criminal liability can be equated with error in the broadest sense [18]. According to Roeslan Saleh, criminal responsibility is defined as a person who is responsible for what he does, he must do the act with free will. In fact, if that is the case, they do not discuss the conception of criminal responsibility, but rather talk about measures of being responsible and therefore it is considered that there is criminal responsibility [19].

Furthermore, Roeslan Saleh said that They seek and emphasize what conditions must be there, so that someone can be said to be responsible for a criminal act. But the results of his research do not provide any information about what it means that a person is responsible for his actions. It is precisely the answer to this question that needs to be thought about. Accountability and punishment are expressions heard and used in daily conversations in morals, religion and law. The three elements are related to one another and rooted in a common state, namely the existence of a violation of a system of rules. This system of rules can be broad and varied (civil law, criminal law, moral rules and so on). What the three have in common is that they include a set of rules about behavior followed by each particular group. So, the system gives birth to the conception of mistakes, accountability, and punishment is a normative system [20].

George P. Fletcher states in full:

We distinguish between characteristics of the act (wrongful, criminal) and characteristics of the actor (insane, infant). Indeed, the Model Penal Code builds on this distinction by defining insanity as a state of non responbility involving, in part, the absence of "substantial capacity to appreciate the wrongfulness" of the criminal act. This definition would not be 
coherent unless the issue of responsibility were separable from the issue of wrongfulness; if non-responsible acts were not wrongful, it would not make sense to say that insane actor did no appreciate the wrongfulness of his act [21].

\section{Fictitious Order Crime.}

A fictitious order is a criminal act against the law of online transportation through an electronic system where in this case the act can harm the company as a partner of the online transportation driver. Judging from the definition of fictitious orders carried out by online transportation drivers that have self-beneficial properties and can harm other parties, the fictional order criminal act can be categorized as a criminal act of fraud as referred to in Article 378 of the Criminal Code which states whoever is with the intention of benefiting himself or another person unlawfully, using a false name or dignity, by deception, or a series of lies, moving another person to hand over something to him, or to pay a debt or write off a debt, is threatened with fraud by a maximum imprisonment of four years .

However, along with the times, besides being self-beneficial, fictitious orders also have the characteristics and characteristics of criminal acts in the field of information and electronic transactions (cybercrime) using sophisticated equipment, namely through internet network access, so fictitious orders can also be categorized as a cybercrime crime. as referred to in Article 35 Jo Article 51 of Law Number 11 Year 2008 concerning Electronic Information and Transactions. Based on the provisions of Article 35 of Law Number 11 of 2008 concerning Electronic Information and Transactions, it states "Every person intentionally and without right or against the law manipulates, creates, changes, removes, destroys Electronic Information and / or Electronic Documents with the aim that the Electronic Information and / or Electronic Documents are considered as if the data is authentic". Based on the provisions of the Article above, it can be concluded that the elements in the fictitious order crime are as follows:

1. Everyone;

2. Intentionally and without right against the law;

3. Perform manipulation, creation, alteration, removal, and destruction of electronic information;

4. With the aim as if the data were authentic.

\section{Accountability of Fictitious Order Perpetrators Based on the provisions of the Sanctions for Service Companies PT. Grab}

Based on the results of research conducted at PT. Grab Teknologi Indonesia, there are 20 (twenty) forms of possible violations committed by grab drivers, including:

1. Fighting / taking action outside the norm of decency / behaving violently either verbally or non-verbally, physically or non-physically, including acts of threatening / intimidating / frightening / harassing SARA / physical / sexual, by any means and media to any party, whether with Grab passengers / employees / fellow Grab partners / restaurants registered in the Grab Food platform / customers / other road users;

2. Conducting sexual and non-sexual harassment towards passengers either in person, by phone, text message or in any way;

3. Using a Grab application that comes from an unofficial source or other application that can interfere / harm / cheat any party, including Grab;

4. Using a device that has changed its basic security level (example: Android Root / iOS Jailbreak) 
5. Contact customers / passengers / restaurants registered on the GrabFood platform for reasons that are not related to the Grab application service through any media such as via sms, telephone, letter, email, messaging application, social media or others, whether in the form of text, voice, image to video;

6. Disseminate personal data / information belonging to passengers / customers / other Grab partners / restaurants registered in the GrabFood platform through any media (for example: online media, print media, messaging applications, and others);

7. Having a passenger / subscription order;

8. Lending or buying and selling Grab Partner accounts;

9. Cheating or manipulating Grab's own system or someone else's for any reason, including to get orders / additional money / bonus / incentives;

10. Participate in any illegal demonstrations against Grab and provoke other partners to carry out activities that can damage public facilities or harm other parties, and or harm any party, including Grab (for example: anarchist actions, destruction of facilities, raids, boycotting the use of applications Grab);

11. Passengers complained / complained to the Authorities (example: Police) and the Partner was found guilty;

12. Spread or persuade others to spread untrue / lie / fake news that can damage the good name of the company or its employees, either directly (for example: public speeches) or indirectly through any media (for example: social media, print media), causing concern for Grab Partners and / or losses for any party, including Grab;

13. Offer and give goods or money to Grab Staff for the purpose of violating regulations;

14. Carry out and / or complete orders / orders without picking up passengers;

15. Misusing the account of a Grab service user (the Grab application) is no exception by using other media (platform / application partners other than Grab) to make fictitious orders for one's own needs or for other people, whether done alone or in collaboration with other parties (for example: Grab partners others, restaurant partners, shop owners);

16. Committing criminal / criminal acts against passengers or anyone either during the trip or afterwards (for example: committing violence, assault, harassment, terrorism, theft, murder, etc.);

17. Found or reported carrying firearms / sharp weapons and / or illegal drugs while carrying passengers;

18. Driving under the influence of alcohol or drugs (Narcotics, Psychotropics and other Addictive Substances);

19. Involved in cases that require investigation, either directly or indirectly, when running a service, including difficult to work with / uncooperative / deliberately slowing down the investigation process;

20. Identified using falsified documents including personal identity (example documents: KTP, SIM, KK, SKCK, etc.) and or not carrying out verification as required or required [22].

Based on the results of interviews with researchers at PT. Grab Indonesia stated that the forms of fictitious orders that drivers take include:

1. Using the Grab application that comes from an unofficial source or other application that can interfere / harm / cheat any party, including Grab;

2. Using a device that has changed its basic security level (example: Android Root / iOS Jailbreak) 
3. Contact customers / passengers / restaurants registered on the GrabFood platform for reasons that are not related to the Grab application service through any media such as via sms, telephone, letter, email, messaging application, social media or others, whether in the form of text, voice, image to video;

4. Disseminate personal data / information belonging to passengers / customers / other Grab partners / restaurants registered in the GrabFood platform through any media (for example: online media, print media, messaging applications, and others);

5. Lending or buying and selling Grab Partner accounts;

6. Cheating or manipulating Grab's own system or someone else's for any reason, including to get orders / additional money / bonus / incentives;

7. Carry out and / or complete orders / orders without picking up passengers;

8. Misusing the account of a Grab service user (the Grab application) is no exception by using other media (platform / application partners other than Grab) to make fictitious orders for one's own needs or for other people's needs, either alone or in collaboration with other parties (for example: Grab others, restaurant partners, shop owners); [22].

Factors That Cause the Occurrence of Fictitious Orders (Fraud) at PT. Grab.

Based on the previous explanation about the legal relationship between the online grab driver and PT. Grab Indonesia is a partnership relationship that has an equal position and does not regulate wages, severance pay and working hours unlike the work agreement between workers and employers which regulates wages, severance pay and working hours, besides that there is a unilateral policy set by PT. Grab Indonesia, which is always detrimental to grab drivers, will certainly affect income which can hamper the economic needs of online grab drivers so that grab drivers often do fictitious orders to get bonuses and more income to sustain the economic needs of online grab drivers.

\subsection{Fictive Orderan Criminal Treatment in Indonesia And Malaysia 3.3.1 Handling the Crime of Fictitious Order in Indonesia}

\section{Prevention of Crime}

Barda Nawawi said that efforts to combat crime need to be pursued through a policy approach in the sense that:

a. There is integration (integrality) between criminal politics and social politics.

b. There is integration (integrality) between crime prevention efforts with "penal" and "non penal' [23].

Efforts to integrate in the context of overcoming crime can be carried out in two ways, namely:

\section{Penal Mediation}

According to Barda Nawawi, his view is that penal mediation has several terms, including "Mediation in criminal cases" or "mediation in penal matters" which in Dutch terms is called "strafbemiddeling", and then in German it is called "Der aubengerich." -tliche tatausgleich ", then in French it is called" mediation penale ". Furthermore, it is said that because penal mediation mainly brings together the perpetrator of a criminal offense and the victim, penal mediation is often known as" victim offender mediation' [24]

Currently, the National Police has started penal mediation since the issuance of the letter of the Chief of Police No. Pol: B / 3022 / XII / 2009 / SDEOPS. December 14, 2009 regarding case handling through Alternative Dispute Resolution (hereinafter referred to as ADR). This means that the letter of the National Police Chief is valid for both parties (both the perpetrator 
and the victim) if they agree to mediate on the condition that the criminal offense committed is a minor crime.

Based on the foregoing, penal mediation as an alternative to the criminal justice system in Indonesia is expected to be able to tackle criminal acts and make it easier for law enforcers to settle a criminal case, so that according to the author, penal mediation has the following general principles:

1. The implementation of penal mediation must be approved by both parties, namely the perpetrator and the victim so that the matters stated in the mediation result are based on the agreement of both parties;

2. Penal mediation is carried out and provided in every stage of the legal process from the level of investigation, prosecution to trial.

Based on the foregoing thoughts, it is necessary to develop the principles contained in the settlement of cases outside the court, namely:

1. There is a need for a Mediator

In Conflict Handling. In this case the mediator must be able to convince those who are involved in the conflict by prioritizing the communication process. In communication that if crime is allowed to cause interpersonal conflict, it sometimes even extends to mass conflict, the mediator must be able to explain the importance of mediation in order to relieve hurt feelings and try to restore that these incidents were mistakes that must be corrected on the basis of mutual understanding.

2. Prioritizing Process Quality

In conducting mediation what is sought is the quality of the process, not the result of determining the losers and the winners, here in the process it is necessary to have awareness from each party to respect each other until a win-win solution is reached.

3. Informal Mediation Process

In mediation, efforts are made to avoid formal discussions, so that the parties involved feel mutually respected.

4. Get All Involved

In the Mediation Process In mediation everything must be planted with a sense of responsibility regarding the results to be achieved in conducting penal mediation. In involving all parties, there is a culture of shame and mutual forgiveness with the aim that if the mediation process is successful, all parties will not feel embarrassed.

\section{Non-Penal Mediation}

Non-penal criminal justice system policy is a settlement of criminal cases through the court. So that the implementation of the non-penal criminal justice system does not directly affect the prevention of a criminal act. Basically, non-penal focuses more on the deterrent effect of the perpetrator of a criminal act so that the criminal offender does not repeat it.

\subsubsection{Handling the Crime of Fictitious Order in Malaysia}

In Indonesia, offenders of fictitious order crimes may be subject to sanctions as stipulated in Article 378 of the Criminal Code and specifically the perpetrators of fictitious order crimes can also be given sanctions as regulated in Article 35 Jo. Article 51 of Law Number 11 of 2008 concerning Information and Transactions Electronic. Based on the provisions of Article 35 of Law Number 11 of 2008 concerning Electronic Information and Transactions, it states: "Every person intentionally and without right or against the law manipulates, creates, changes, removes, destroys Electronic Information and / or Electronic 
Documents with the aim that the Electronic Information and / or Electronic Documents are considered as if the data is authentic".

Meanwhile, in Malaysia, the criminal act of fraud in Malaysia is regulated in various Articles including [25].

Article 25 of the Malaysian Criminal Code which states

"A person is said to be doing something fraudulently if he does the act with the intention of deceiving, but not in any other way."

Article 28 which states

"Someone is said to be" counterfeiting "which causes an item to resemble another item, that is meant to be fraudulent, or knowing in this way fraud may be committed".

Article 415 which states

"Whoever by tricking someone fraudulently or dishonestly persuades the deceived person not to hand over property to someone, or to agree that someone will keep property, or deliberately persuades a trusted person to do or not do something he does not want to do. or ignore him if he is not deceived, and because of that act or neglect causes or may cause damage or injury to that person in the physical, spiritual, good name or property sense, is called "deceiving".

Article 416 which states

"Deceive by disguising yourself as someone", if he cheats by pretending to be someone else, or by knowing he is replacing someone with another, or acting that he or that another person is someone other than him or someone else who really is. Explanation - The offense is committed, whether the person taken as a disguise is a person in reality or an image".

Article 417 states

"Anyone who defrauds is punishable by imprisonment for a period of up to one year, or with a fine, or both."

Article 418 which states

"Anyone who deceives with the knowledge that he may thereby cause unlawful harm to a person whose interest in a transaction related to the fraud, is bound either by law, or by a contract according to law to protect it, shall be punished by punishment for a period of up to three. years or with a fine or both".

Article 419 which states

"Anyone who defrauds by posing as someone is punishable by imprisonment for a period of up to three years or a fine or both."

Article 420 which states

"Anyone who deceives and therefore dishonestly persuades someone who is tricked into handing over property to someone, or makes, changes or destroys all or part of securities or something that is signed or stamped and which can be converted into securities, shall be punished by imprisonment for a period of up to seven years, and also a fine".

Based on the articles related to the criminal act of fraud as contained in the Malaysian Criminal Code, according to the author of the crime of fictitious order based on Article 418 which states "Anyone who deceives with the knowledge that he may thereby cause unlawful harm to a person whose interest in a transaction related to the fraud, is bound either by law, or by a contract according to law to protect it, shall be punished by punishment for a period of up to three. years or with a fine or both".

\section{Prevention of Crime in Malaysia}

The legal system in the world is divided into 4, namely anglo saxon (common law), Europian continental (civil law), Islamic law (Islamic legal system) and customary law 
systems. The legal system in Malaysia and in Indonesia is different. This is because Malaysia practices the Anglo Saxon (common law) legal system when Indonesia practices the Europian Continental legal system (civil lam / civil law).

As a country that adheres to the anglo saxon (common law) legal system in Malaysia, there are four sources of law, namely written law, customary law, Islamic law and customary law. Written law consists of federal and state constitutions, federal parliamentary legislation and state legislation, and additional legislation (laws and regulations). Additional legislation is made by bodies or persons authorized to perform these tasks under federal parliamentary or state legislation.

Whereas there are similarities and differences in regulations regarding the handling of criminal acts in Indonesia and Malaysia. In Indonesia, handling of criminal acts can be pursued in two ways, namely Penal mediation and non-Penal mediation (trial process), while in Malaysia, criminal action can also be handled through courts in Malaysia as well as native courts or better known as the customary law system.

\section{Conclusion}

Based on the results of the research and discussion above, it can be considered as follows: Whereas the legal relationship between online transportation drivers and online transportation companies is based on the principle of an agreement which is subject to Article 1313 of the Civil Code. The partnership agreement contract is based on three parties, namely the driver, the provider, namely PT. Grab Teknologi Indonesia, and application users. That in the partnership agreement between the driver and the Grab Company, the provisions of the unilateral policy set by PT. Grab Indonesia and this policy will certainly affect income so that drivers who take it often do fictitious orders to get bonuses and more income to sustain the economic needs of online grab drivers.

Whereas there are similarities and similarities in regulating criminal action in Indonesia and Malaysia. In Indonesia, the prevention of criminal acts can be achieved in two ways, namely penal mediation and non-penal mediation (trial process), while in Malaysia, criminal action can be handled through courts in Malaysia as well as indigenous courts (district courts) or better known as the customary law system.

\section{Suggestions}

Based on the above conclusions, the authors suggest the following:

1. That the partnership agreement must be regulated strictly in the law in order to provide legal protection for online transportation drivers whether as partners or employees and also the ministry that is authorized to regulate the existence of online transportation.

2. That the number of Grab companies must take various ways to minimize fictitious orders. Such as frequently communicating with drivers, tightening the Grab system, adjusting the number of drivers with consumers so that there are not too many drivers, which triggers fictitious orders, and also minimizes incentives.

3. For law enforcers, the government and Grab companies in Indonesia and Malaysia in overcoming criminal acts, it is hoped that the settlement can be carried out through penal mediation or legal settlement that applies in community life such as customary law that reaches deliberation and consensus. 


\section{References}

[1] Ahmad M Ramli, 2007, Menuju Kepastian Hukum di Bidang : Informasi dan Transaksi Elektronik, Depertemen Komunikasi dan Informatika Republik Indonesia, Jakarta.

[2] Ahmad M Ramli, 2004, Cyber Law dan HAKI dalam Sistem Hukum Indonesia, Refika Aditama, Jakarta.

[3] Paulus Hadisuprapto, "Juvenile Delinquecy”, Citra Aditya Bakti, Bandung.

[4] Barda Nawawi Arief, dalam "Bunga Rampai Kebijakan Hukum Pidana Perkembangan Penyusunan Konsep KUHP Baru”, Kencana, 2008, Jakarta, hlm.

[5] Teguh Prasetyo, Hukum Pidana, Rajawali Pers, Yogyakarta, 2010.

[6] Elvian Sudirman, "Perlindungan Hukum Bagi Perlindungan Hukum Bagi Pengguna Jasa Transportasi Online di Kota Makasar (Studi Pengguna Jasa Grab Motor (Grab Bike) di Lingkungan Fakultas Ilmu Sosial UNM". Jurnal Universitas Makasar.

[7] R Soeroso, 2008, Dasar-Dasar Ilmu Hukum, Cet 1, Sinar Grafika, Jakarta.

[8] Ishaq, 2005, Pegantar Ilmu Hukum, Cet ke VII, Sinar Grafika, Jakarta.

[9] M. Teguh Pengestu, 2019, "Pokok-Pokok Hukum Kontrak", Sosial Politik Genius, Makasar.

[10] M. Yahya Harahap, 1986, Segi-Segi Hukum perjanjian, Alumni, Bandung.

[11] Teguh Prasetyo, dalam Hukum Pidana, Rajawali Pers, Yogyakarta, 2010

[12] P.A.F. Lamintang,” Dasar-Dasar Hukum Pidana Indonesia”, Citra Aditya Bakti, Bandung, 2011

[13] Sudarto, 1987, Hukum Pidana I, Badan Penyedia Bahan-Bahan Kuliah Fakultas Hukum Universitas Diponegoro, Semarang.

[14] Roeslan Saleh, 1980, Pikiran-Pikiran Tentang Pertanggunjawaban Pidana, Cetakan Pertama, Rajawali Press, Jakarta.

[15] George P.Fletcher, 2000, Rethinking Criminal Law, Ofxord University Press.

[16] Subekti,1975, Aneka Perjanjian, Citra Adtiya Bakti, Bandung.

[17] Dora Kusumastuti, 2019, Perjanjian Kredit Perbankan Dalam Perspektif Welfare State, Budi Utama,Jakarta

[18] Mas Muanam, dkk, 2009, Rekonstruksi Kontrak Kerja Outsourcing, Cet I, Deepublish, CV.Budi Utama, Yogyakarta.

[19] Subekti, R.Tjitrosudibio, 1992, Kitab Undang Undang Hukum Perdata, Pradnya Pramita, Jakarta.

[20] The Kian Wie, 1992, Dialog Kemitraan dan Keterkaitan Usaha Besar dan Kecil dalam Sektor Industri Pengolahan, Gramedia, Jakarta.

[21] Lora Vivian, Tinjauan Hukum Terhadap Perjanjian Kemitraan Antara PT.Gojek Indonesia Cabang Medan dengan Driver Gojek, Repositori Institusi USU, 2018.

[22] Teguh Prasetyo, Hukum Pidana, Rajawali Pers, Yogyakarta, 2010

[23] Arnold Mangara Tua, 2014, "Perbandingan Hukum Tindak Pidana Penipuan Menurut Pasal 378 Kuhp Indonesia Dan Pasal 415 Kuhp Malaysia, Perpustakaan-Universitas Trisakti.

[24] Luthvi Febryka Nola, 2018, "Perjanjian Kemitraan vs Perjanjian Kerja Bagi Pengemudi Ojek Online", Pusat Penelitian Badan keahlian DPR RI Gd. Nusantara I, Lt. 2, Jakarta Pusat.

[25] Elvian Sudirman, "Perlindungan Hukum Bagi Perlindungan Hukum Bagi Pengguna Jasa Transportasi Online di Kota Makasar (Studi Pengguna Jasa Grab Motor (Grab Bike) di Lingkungan Fakultas Ilmu Sosial UNM". Jurnal Universitas Makasar

[26] https://www.grab.com/id/kodeetik/, Diunduh pada tanggal 18 Juni 2020, pukul 21.00Wib.

[27] http://www.negara hukum.com/hukum/pengertian-tindak-pidana.html diakses tanggal 6 Maret 2020. 